UDC 623.4.015.4

DOI: https://doi.org/10.18485/iipe_ria.2020.71.1180.1

Biblid 0543-3657, 71 (2020)

Vol. LXXI, No. 1180, pp. 5-26

Original paper

\title{
THE LATE MODERN WARFARE AND CONTROVERSIES OF NON-LETHALITY
}

\begin{abstract}
Srđan T. KORAĆ ${ }^{1}$
Abstract: The article seeks to investigate how the practice of non-lethality, built on recent advances in armament technology, may affect the ontology of warfare in the 21 st century by turning enemy soldiers and civilian population of other countries into deviant outlaws devoid of moral value "naturally" attributed to "civilised" nations gathered under the (neo)liberal global order. The author analyses the practice of non-lethality in the context of military operations within the framework of US/West policing over the global periphery. The paper hypothesises that the anticipated development of non-lethal weapons raises several controversies related to the projected moral insensitivity of interventionist troops in the treatment of enemy fighters/combatants and the civilian population. The hypothesis is addressed by the critical approach to international security and ontology of warfare, as well as by philosophy of mind and normative approach to moral agency. The author concludes that the Western vision of war as a foreign policy instrument, entirely "sanitised" of the risk of moral wrongdoings, seems to turn a blind eye on the plausible negative effects of non-lethal weapons in combat situations. Contrary to expectations and military-strategic visions, the practice of non-lethality, combined with the manhunt, is likely to eventually oust enemy soldiers and civilians from the realm of moral concerns integral to military ethics.

Key words: non-lethality, non-lethal weapons, the ontology of warfare, military intervention, military technology, armament, military ethics, moral agency.
\end{abstract}

\footnotetext{
${ }^{1}$ Senior Research Fellow, the Institute of International Politics and Economics, Belgrade.

E-mail: srdjan@diplomacy.bg.ac.rs

The paper presents findings of a study developed as a part of the research project "Serbia and challenges in international relations in 2020", financed by the Ministry of Education, Science, and Technological Development of the Republic of Serbia, and conducted by the Institute of International Politics and Economics, Belgrade.
} 


\section{NON-LETHALITY AS A TECHNOLOGICAL RESPONSE TO CASUALTY-AVERSION WESTERN INTERVENTIONISM}

Warfare has been an ancient social practice centred around political collectives deliberately using the armed struggle to impose their will on each other. In the early 21 st century, the leading powers of the global centre gradually transformed and, side-by-side, reframed military interventions to control the policy of the "uncivilised" global periphery. Maja Zehfuss argues that this interventionist disposition has been justified in the political as much as the idealistic claim that the global centre has the ability and responsibility to help make the world a better place because it brings benefits to those on the receiving end (2018, 3-9). She draws attention to an excessive enthusiasm for global ethics that led to misinterpretation of the Western-style of the late modern warfare as "constrained by ethics and therefore somehow less violent, more benign" $(2018,9)$. The apprehension over war as an instrument of ethics culminated in the contemporary warfare taking on features of an anti-crime policy based on the methodology of policing, criminal justice, and the penitentiary system. In my recent work, I suggested that the main goal of late modern war as a global anti-crime policy is to preserve world peace grounded in moral values of the (neo)liberal order by restraining "deviant" behaviour of various warring-criminal-terrorist entities across the global periphery (Korać 2018). The imperial policy of disciplining the non-western periphery follows the corporate logic of classifying individuals and societies into the cooperative and non-cooperative sections in line with their utility for the global division of labour. Besides, the enemy is no longer a respected soldier of a rival army, but is now reduced to a criminal whose behaviour justifies devaluing his personality; he is an individual unworthy of living in the (neo)liberal order.

As a plausible avenue of democratic legitimisation of never-ending disciplining warfare, Western military and political leaderships whole-heartedly embrace the notion of sanitisation/purification of war. This idea reveals the political strategy of discourse manipulation as a means to keep out of the public eye morbid and sordid consequences of warfare by broadcasting highly aestheticized video images of bloodless and costless combat operations in the media (Eken 2017). As Derek Gregory put it, "Death is no longer seen as part of life, as in other cultural and social formations, but is sequestered in screened and medicalized spaces" (2008, 20). On the other side, the desire to minimise losses of human life and protect human rights, and treating of enemy fighters/combatants as ordinary criminals seem that do not require traditional military capabilities and weaponry in disciplining non-cooperative entities from the global periphery. ${ }^{2}$ To provide a more adequate

\footnotetext{
${ }^{2}$ I use the terms "fighter" and "combatant" side by side, although international humanitarian law makes a distinction between two categories on the ground whether the hostilities are international
} 
response to a plethora of asymmetrical threats in urban warfare - a typical combat operating environment for the Western military expeditions in failed/rogue states - policing methodologies employed at the national level to maintain public order and security seem to be a more reasonable tool for achieving foreign policy goals in this context (see Steverson 2008, 34-41; McLaughlin 2007, 115-142). Vivienne Jabri argues that the late modern warfare is now transformed into a regulative tool articulated in global terms and intertwined with practices of torture, deportation, state-building, and the like (2007, 59-62).

But then again, the business of war is still about killing and being killed. The affliction of injury upon enemy bodies as well as the destruction and seizure of enemy property are still constitutive elements of the ontology of warfare, and hence normal parts of the human experience. By building on Baudrillard's notion of war as a "reiterative and automated process which constructs a seamless economy of violence", Nordin and Öberg (2015) stress that the ontology of war-as-fighting implicates a highly violent practice although reflecting disrupted symbolic relations between a soldier and a hostile Other (now epitomised in an insurgent, terrorist, civilian). Despite the new ways in which an enemy Other from the global periphery becomes subjected to military violence thanks to the use of advanced targeting tactics, soldiering involves the making of right or wrong decisions about the perpetration of violence and sacrifice of self. For Jabri (2007, 11), aspiration for war in the absence of injury to the self is one that dominates strategic thinking in the West in the age of the late modern warfare. I find the idea of bloodless warfare perfectly condensed in a wish of Colonel George Fenton, Director of the US Marine Corps' Joint Non-Lethal Weapon Directorate, to get dust that can put both enemy combatants and civilians to sleep, so to execute a combat task successfully and avoid casualties at the same time (NATO Parliamentary Assembly 2001).

Not surprisingly, the Colonel's genuine wish has never been a problem in fiction stories and particularly in the science fiction genre. In The Wizard of $\mathrm{O}_{2}$ people happen to fall asleep in the field of poppies with no harm or risk of dying, while in a number of other fictional stories there is always a magic way to safely disable an opponent and get away from a dangerous situation. In A Deepness in the Sky a science fiction novel by American writer Vernor Vinge (1999) - the wire guns shoot out a very thin wire at high velocity. It is enough to point at the general direction of the threat; the wire wraps around and catches into the target, but it does not penetrate deep enough to be lethal. In Vinge's imagination, targeted persons are left unable to move because of both the pain and their limbs being somewhat restrained. After the removal of the wire, wounds heal in several days.

or non-international in character. For the purpose of my analysis, I find this distinction irrelevant due to the foggy line between irregular warfare and US/West-led military interventions pursued in the global periphery. The focus here is on the same function they perform. 
Another typical piece of imaginary technology of tomorrow is an ion cannon as a sort of particle cannon, which projects ionised particles to damage various electronic devices and systems. Similar to the ion cannon is the phased polaron cannon that appears in the legendary sci-fi tv series Star Trek; it is an energy weapon that emits a beam of polaron particle. Carbon-freezing as the process by which liquid carbonite is flash-frozen into a solid-state took place in one of the most successful and influential franchises in film history - the nine-sequel Star Wars saga, notably in episodes Star Wars: The Empire Strikes Back, Star Wars: Return of the Jedi, and Star Wars: The Clone Wars. This hypothetical weapon has multiple uses, largely to temporarily disable individuals or entire groups of enemies (who can survive but with hibernation sickness).

Common to all described imagined weapons are non-lethal characteristics that bring the heightened theatricality of the combat scenes on the cinema screen but almost entirely purified from the gloomy reality of the battlefield. Will warfare centred around the idea and practice of non-lethality become nothing more than an organised drama with toys in soldiers' hands against the background of a standard operating behaviour in fighting? I suppose not. The seductive sci-fi fantasies about magical devices belong rather to the realm of wild futuristic fantasy than they correspond to the world of plausible science, as they are not within reach of the current scientific and technological advances in biology, chemistry, and physics. For the purpose of this article, I refer to a definition of non-lethal weapons (also described as soft-kill, less-than-lethal, sub-lethal weapons) synthesised from essential elements provided in several other definitions:

Non-lethal weapons are weapons whose physical and operational features cause temporary small-scale incapacitation that can be cancelled later, i.e. weapons designed and employed neither to cause fatalities and irreversible injuries to personnel nor undesired damage to property, infrastructure and the environment (see NATO Parliamentary Assembly 2001; US Department of Defense 2018; Kaurin 2010, 102; Gross 2017, 122-124).

The class of weapons collectively referred to as "non-lethal" permits the ability to better match the weapon to the objectives of military interventions across the global periphery, thousands of miles away from a wide network of overseas military bases. Unlike conventional weapons defined by their potential to inflict death or severe injuries, the operational effectiveness of non-lethal weapons seem to more adequately meet the political requirements for a responsible, economically less expensive, and life-conserving foreign policy aimed at containing and defeating insurgencies. Non-lethal weapons have been expected to provide greater flexibility to the use of force in combat missions and faster response to enemy actions so that to neutralise threats on the battlefield without resorting to deadly force. Non-lethal weapon systems can be constructed as a stand-alone weapon or as an adjunct to conventional weapons, providing enough room for soldier's choice on which level 
of force at the scale of the-use-of-force continuum is adequate to meet the needs of the specific combat situation in the most effective way (Small Arms Survey 2020).

The application of the Fourth Industrial Revolution technologies in the design and construction of non-lethal weapons gives them the unique structural competencies that enable their specific role in military strategies and operational plans. Siniscalchi (1998) identifies the following unique features: 1) precision, 2) radius, 3) repeatability, and 4) selectivity. Firstly, unlike conventional weapons, precision gives non-lethal weapons the capability to control the destructive effects by attacking only selected components of the enemy's military infrastructure, combat equipment, and/or manpower. Secondly, non-lethal weapons, in general, can have a far larger combat radius (a countrywide radius in the case of biological weapons) and can destroy enemy's equipment, even when it is scattered over a large area or when it is difficult to detect exactly which are the critical infrastructure objects. Thirdly, bearing in mind the continuous development of adverse countermeasures, the credibility of non-lethal weapons in terms of achieving planned/desired combat performance is assumed primarily from the certainty that it will be able to repeat the same effects in different combat situations, even within the reach of hostile actions. Fourthly, the purpose of non-lethal weapons to avoid human suffering and material damage opens doors for designing and implementing far more flexible foreign policy and military strategies and action plans, which would be unsustainable if only conventional weapons were used. Moreover, diverse nonlethal weapons are designed to disable a human target by affecting her/his psychological, physical or both systems with projectiles, chemicals, electricity, light and sound to either obstruct or block human sensory systems (i.e. touch, sight, hearing and smell) or induce pain.

There must always be intentionality behind the technical details as the prime cause of the use of any type of weaponry. Intentionality is the directedness of the mind upon something, i.e., the mind's capacity to direct itself on things (see Searle 1999, 1-4). Arnauld holds that every perception is the perception of something because it has a representational content and thus is representative of some object ([1683] 1990,381). This representative character is an intrinsic feature of the perceptual act and is what gives the act its directedness-towards-an-object. Since the action is the condition of satisfaction of the intention to perform it, I find Heidegger's thesis that intentionality is primarily a matter of action rather than consciousness helpful in the consideration of the practice of non-lethality. For Heidegger, the most basic form of intentionality is agency, which means that the world is a place of many possibilities for action ready to be interpreted by enacting some of the possibilities disclosed by understanding the world as a setting for action (Heidegger, 1982). Unlike human beings, structural features of weapons do not have intentionality in themselves. They do not have "original intentionality" but intentionality derived from the interpretation of their design 
characteristics by the constructor and the end-user (military planners and commanders). Therefore, there is only the original intentionality that stems from the agency of constructors and military leaders. Military leaders and planners imagine and interpret the desired technical features of a weapon and define their specific needs in the form of a set of requirements for designers and constructors. Since intentionality implies a present activity directed towards a future by working out possibilities, the primary way in which military leaders intend a non-lethal weapon as a military tool has to be in an overt act of employing it on the battlefield. Still, is it all about design and technology?

The utilitarian reasoning about whether and in what way our free will makes an object a weapon in our hands seems to obscure the more important question of whether the moral reasons for its use are sound, with a view to the damage inflicted upon other people and the moral obligations to treat all human beings as of equal value. The way in which a weapon kills is essential as well, because over time through practice - it develops gradually into the logic of killing consolidated in dominant normative order within which war operations take place. That is why Nisha Shah (2017) sets out to analyse how lethality is being legitimatised through the advancement in technology and design of weapons aspired for an increase in the ability damage, and combined with a particular method of killing adequately to the weapon design, especially those characteristics that support ethical conduct in war. Shah emphasises that the ways in which the technical properties of a weapon are standardised are not only aimed at increasing its efficiency; they also constitute the legitimacy of war as social practice because weapons inflict injuries and death and at the same time specify acceptable ways in which death occurs $(2017,563-$ 564). Shah explains that the acceptability of a type of weapon as an agent of destruction leans on the ways in which it is constituted by its technical properties, instructions for its use, military strategy, human ingenuity, and propensity to war; yet, it is also affected by moral worldviews and social conventions on what military objectives and ways of the use of armed force are (in)appropriate $(2017,557)$.

Moral behaviour is impossible without a free will as the latter is the ability to make choices between different possible courses of action autonomously. The praise or blame for morally good or bad actions is being ascribed not to the action itself, but to an agent who did that action. Swinburne claims that belief in the reality of moral responsibility is epistemically basic and since that moral responsibility entails free will, we feel it is not right to praise or blame someone for their unintentional actions $(2013,210-229)$. It is pertinent to see how the strategic employment of non-lethality in military operations raises the question of the moral acceptability of this type of weapon in terms of the (in)appropriateness of its combat use against the enemy. The point of departure for my analysis is the claim that an anticipated development of non-lethal weapons may raise several controversies related to the projected moral insensitivity of interventionist troops 
of the global centre in the treatment of enemy fighters/combatants and the civilian population of the global periphery. I will critically interrogate whether the practice of non-lethality within the framework of US/West policing may affect the ontology of warfare by turning the enemy fighters and the civilian population into deviant outlaws devoid of moral value "naturally" attributed to "civilised" nations gathered under the (neo)liberal global order. My analysis will embrace manufactured, conceived and non-lethal weapons currently under development, primarily based on technologies of directed energy and sound. I will also reflect on the ethical quandaries that may raise from operationally relevant structural characteristics of non-lethal weapons, such as precision, radius, repeatability, and selectivity.

\section{NON-LETHALITY AND INSENSITIVE MORAL AGENCY}

Martin Van Creveld stresses that the will to die on the battlefield is a far more constitutive element of warfare than it is the will to kill because war begins only when a group of people intentionally accept the risk of being killed (Van Creveld 1991, 159-160). The will to fight, legitimised by people's support to the long-term political objectives of a warring entity, is acknowledged as vital in the context of irregular warfare and has never had anything to do with the amount of resources insurgents have at hand (Porch 2013; Scheipers 2014). Some military historians and scientists brought to light unflattering truth about the natural reluctance, and even refusal, of the majority of ordinary men to kill their enemy counterparts in the close combat situations (Watson 1980; Jones 2006). Being one of the most prominent in that group of scholars, Dave Grossman (1996) refers to the massive empirical evidence in arguing that soldiers experience the greatest resistance when they see the enemy clearly or stare them in the eyes, i.e., when it becomes obvious that they are killing someone just like themselves.

The practice of non-lethality might soften the resistance of soldiers to engage in close combat against insurgents who always easily fit with the civilian population. The supporting argument for the future development of this type of weapon is largely based on the fact of benign intervention on the body as the result of its operational employment, where benignity plays a role of a desirable property because it safeguards the sanctity of the body and human life. Unlike conventional weapons, which have a binary option "try to kill or do nothing", the use of nonlethal weapons opens up numerous possibilities for limiting the damage and suffering of innocent people, while at the same time providing military planners and commanders with a more precise manner in which the force can be used during combat - combined with a wider scope of combat actions and better distinction between combatants and civilians.

As the generally accepted moral concern of the late modern warfare is to reduce suffering, the way of waging wars ought to be such as to avoid cruelty to others. 
Non-lethal weapons offer operational options more adequate to the modern rules of warfare aimed at reducing unnecessary or unintentional casualties and collateral damage. For scholars like Pauline Kaurin (2010, 109-112) and John B. Alexander $(1999,24)$, the practice of non-lethality is supposed to slow down the trajectory of violence so that participants in combat operations have enough room for sound ethical decision-making and get rid of the psychological burden of thinking about killing. Non-lethal weapons enable military planners to project more subtly the lowest effective level of the use of force meeting the level of adversary threat and to more easily decide on the use of the "shoot first, ask questions later" tactic. The problem with the tactic is it presupposes taking actions with serious consequences without delay while preserving the benefits of the surprise effect that occurs due to concealment of intentions. This can lead to the deliberate targeting of clearly innocent persons as calculated collateral damage being a function of accomplishing the combat mission.

Conventional weapons are designed to kill or incapacitate the enemy so that their very purpose contradicts the moral norms and laws of armed conflict. In contrast, since not being intended to kill, non-lethal weapons would expand the legitimisation ground for the use of force and thus turn civilians into legitimate targets because their direct use against civilians is not prohibited nor collateral damage can be considered contrary to international rules of war (Fidler 2001, 201204). Never-ending wars led by US/West coalitions against rogue/failed states to suppress anti-(neo)liberal insurgencies across the global periphery might seem to have broken down the ontological distinction between law enforcement operations bounded by strict rules aimed at human rights protection and fighting wars by the rules of armed conflict. Counter-insurgency operations now include law enforcement tactics and tools regularly, which additionally make more confusing when policing stops and soldiering begins, and vice versa. The concept of nonlethality bears upon the intention to temporarily disrupt the operation of the human body without causing permanent injury or death, which makes this idea so at odds with the war's constitutive objective to produce irreversible injury and death. In his study of moral quandaries that have emerged from the use of non-lethal weapons (in particular, incapacitating chemical agents and dazzling laser devices) by US forces in Iraq, Christian Enemark (2008) points out that the practice of non-lethality - as an ethically superior alternative to inflicting death and suffering - is being undermined by the failure of its accurate operationalisation in the midst of the uncertainty, friction, chaos, and ambiguity in situational awareness in combat (illustrated by the metaphor "fog of war"). Enemark shows that the non-lethality has been legitimised contingently so far, from case to case, as the current interpretation of the principles of discrimination and proportionality does not provide clear guidance and, thus, an ethically preferable instrument of interventionist forces. 
The attribute "non-lethal" can be somewhat misleading. Any weapon has the potential to generate effects that do not match the intent of its user (and more indirectly, its planner and designer). The non-lethal weapons can certainly be fatal if used improperly, or contrary to the instructions of the designer or manufacturer. Even non-lethal weapons are not without shortcomings in terms of risks to the safety of the civilian population; those risks primarily may stem from improper use caused by deficient or unsound military training. For instance, some non-lethal weapons contain chemical agents designed to act on the enemy's central nervous system. All of that raised reasonable concerns about how non-lethal weapons could be misused, which can be summed up in the argument that this type of weapon could be used to torture prisoners and illegal, even covert, population control. In fact, the constructors and military planners themselves have considered thoroughly moral and legal controversies from the very beginning (Alexander 2001, 186-188).

A professor of military ethics, Pauline Kaurin (2010, 103), criticises the efforts of some theorists to mislead the idea that non-lethality makes coping with moral dilemmas redundant, especially when it comes to distinguishing combatants from non-combatants because the non-lethal force can supposedly first disable the suspected enemy combatants, and then, later, identify who really is a (enemy) soldier and who is not. Moreover, there has been an illusion created that advances in the technology of non-lethality and subsequent improvements in operational characteristics of this type of weapons will by default be able to make a distinction between fighters and civilians - to say, almost automatically. Undoubtedly, no technology, no matter how advanced it may become in the future, is likely to be capable of replacing a human being in the chain of command because this type of action requires ethical decision-making and a moral agent with formal training in ethics. Kaurin remarks that only man is what makes any weapon, even a non-lethal one, "capable" of distinction between combatants and civilians; only man can use the weapon in a manner that will ensure the distinction is made according to the laws of armed conflict $(2010,103)$.

The assumption that non-lethal weapons may lower fatalities and collateral damage has nothing to do with the question of how commanders and soldiers would combine the practice of non-lethality with the principles of discrimination and proportionality on the battlefield. Non-lethality does not erase the moral dilemma (typical of conventional weapons) about whether it is permissible to deliberately target non-combatants if they find themselves in the middle of a combat operation, on the way to fire, given their immunity that provides them different treatment comparing to fighters. Stephen Coleman stresses that the use of non-lethal weapons in a fashion that applies the principle of discrimination "after" the use of force is contrary to how this principle is applied to the use of lethal force, which is "before" the use of that force - military personnel is simply not permitted to deliberately target non-combatants (2014, 37-39). Michael Gross 
(2008) warns that the practice of non-lethality is gradually leading to a broadened targeting criterion that then embraces more and more civilians. Targeting civilians in this way ceases to be incidental and becomes intentional. It follows that, albeit it saves lives in the long run, non-lethality against non-combatants makes their immunity meaningless. It turns out that restrictions on the violation of the immunity of non-combatants can be morally more easily justified on the ground that the collateral damage is far less, so it seems that the supposed ethical pros of non-lethal weapons over conventional ones eventually become blurred (Kaurin 2010,104).

Mitigating the effects of combat operations in the form of reducing collateral damage to people and property does not address a moral violation of the principle of discrimination. Kaurin also warns $(2010,105)$ that the empirical material gathered by studying the cases of low-intensity conflicts clearly evidences how the use of non-lethal weapons as precursors to conventional ones actually leads to a higher number of deaths. For instance, if caught in the beam projected by the Active Denial Technology - a sort of weaponised microwave that instantly heats nerve cells in the skin to induce pain without lasting harm - a person feels an immediate heating sensation, which she wants to get away from instinctively. As soon as she moves out of the beam's reach, the sensation disappears virtually immediately. But the Active Denial Technology can be used in a manner in which it may cause harm to disabled enemy fighters who are not able to defend themselves as combat operation develops farther so they cannot escape the beam, perhaps even to the point of being hors de combat. This non-lethal weapon might be used to deliberately inflict pain on civilians, while not causing any lasting (or even detectable) damage to their bodies.

Building her analysis of non-lethal weapons as a means of politics of microinterventions on the body and macro-interventions on population and space on Foucault's teaching on governmentality - which is an offspring of his concept of biopolitics - Seantel Anaiis (2011) argues that this type of weapon reconfigures subjectivity in a way that remains beyond traditional concepts of power. Anaïs shows how the US Department of Defence's official discourse strives to strike a subtle balance between advocating the benefits of non-lethal weapons as a safe, convenient, and morally sensitive military tool and the research output aimed at determining the degree of force that the human body can withstand with no fatal outcome (2011, 546). For instance, the Long-Range Acoustic Device (LRAD) is designed to incapacitate people by projecting sound waves at a high volume to hit the target at up to $152 \mathrm{dbs}$. - enough to cause permanent hearing damage (Atherton 2020). An American journalist who experienced an LRAD attack in the Pittsburgh protests described the effect: "Your brain feels like it's vibrating in a bowl of jelly on the table" (MacDonald-Evoy 2018). Similarly, flash bang grenades (or stun grenades) produce a sudden bright light that causes ocular pain, confusion, and temporary blindness, in combination with the "bang" that is more 
than $165 \mathrm{dbs}$. The desired balance about the degree of weapon's effect that the human body can withstand with no fatal outcome seems not yet to be reached. There have been multiple reports on injuries and deaths, including burns and fatal heart attacks, caused by using flash bangs grenades in police crowd control tactics across the United States (Atherton 2020). An Amnesty International report on human rights impact of less lethal weapons (AI \& ORF 2015, 27) highlights that far-reaching safety risks may stem from scarce information about the medical risks (particularly for vulnerable groups highly sensitive to the weapon's effects), issues of accuracy, and issues of reliability related to possible design flaws and low manufacturing quality.

Non-lethal weapons genuinely are being tailored by scientists, designers, and engineers to push the threshold of undetectable harm up to the highest possible point. NATO report on the human effects of non-lethal technologies adopted in 2006 urged for acquiring data on human effects of the military technologies with the highest potential for effectiveness on the battlefield, but difficult to test due to ethical concerns and strict medical standards on the limit of human exposure (NATO 2006). Coleman suggests that the main goal of the corporate sector is to engineer non-lethal weapons "whose effects are temporary and reversible without any medical intervention but are also unpleasant enough to ensure compliance with the directions of the user" $(2015,199)$. I argue that performing experiments to collect detailed medical information on the highest possible point of undetectable harm to living individuals - and to use gathered data to create conclusions about how to design, develop, and deploy subsequently this type of weaponry - would be inherently immoral because it would treat humans as non-living objects devoid of intrinsic moral value. Identifying when the threshold of severe pain or suffering is crossed and calibrating the levels to keep them within health integrity limits might have an appearance of legitimate bureaucratic procedure euphemistically defined as e.g. standardisation of acceptable levels of harm. The intentionality behind controversial experiments related to non-lethality can be conceptualised by Martin Buber's (1937) notion of the I-It relationship. Buber explains how the encounter between humans as equally worth moral agents (the I-Thou relationship) is oftentimes degraded into a relationship that involves a self-conscious subject and a world of lifeless objects that the subject can measure and manipulate. Along with affecting the human sensory nervous system and brain functions, a non-lethal weapon is a psychological military tool as well, since it may cause a primordial fear of the unknown, common to all people, regardless of the ability to understand causal relations (weapon-injury), and upset members of a warring entity. When we instil fear in the enemy, we have power over him, and we can make him give up the fight, and achieve measurable effects that advance the unit's objectives. In the case of non-lethality, the asymmetry caused by advanced military technology seems to be inherently immoral because of its propensity to transform the war into a 
manhunt of targeted insurgents with no reciprocal risk of death for interventionist troops (Caron 2020). The never-ending search for advancement in the routinised counter-insurgency industrial process of "search and destroy" obviously turns humans into objects stripped of moral value.

The recognition of the wrongness of killing another human being in the fog of war assumes the agency of a morally aware individual. Moral awareness is a critical component of sound moral reasoning and ethical decision-making and moral action. It refers to spontaneous recognition of the ethical aspect of an issue at hand, and the interpretation of a situation in moral terms (Clarkeburn 2002, 443). Moral awareness can be achieved by moral sensitivity, which is coined and defined by James Rest as the ability to recognise that in a situation in which we need to act, an ethical question arises, which we need to answer by choosing the course of action and to act accordingly (Rest 1994). Making good ethical decisions requires moral sensitivity developed in personality, so for a person who is not able to detect an ethical dimension of a situation, we usually say that he is morally insensitive, and thus not likely to choose the morally right course of action. In a combat environment where the morally insensitive professional mindset and behaviour occur due to the complex context of quick moral reasoning under intensive and protracted stress, combatants are likely to indicate moral blindness or the lack of moral response (i.e., moral disengagement). Another negative effect of moral insensitivity on the good moral judgment is insufficient attention rooted in the false perception of the moral intensity level of a certain situation (Jones 1991). On the battleground, a commander or soldier neglects the ethical aspect of a situation if he perceives that it has small importance (i.e., low moral intensity), ignores the risk of misinterpreting the moral aspects of the situation, and eventually makes mistakes inflicting harm on others. Moreover, moral agents tend to miscalculate the negative consequences of their acts and the risk involved, create inaccurate judgments about causal perceptions, and give disproportionately more weight to existing consequences than anticipated consequences.

For most people, war is a social anomaly, and it is normally wrong to deliberately take human life (Young 1979). Albeit the principle of respect for life is now universal, Richard Norman reminds us that the killing of thousands of people in war stops to be utterly wrong; it still is widely accepted as a necessary and inevitable part of our way of life (1995, 36-72). Bearing that in mind, Noam Zohar (2014) argues that it would be misleading to speak of the soldiers' relevant obligation in terms of "preventing" harm to innocent non-combatants. He sees as vital to clear up the issue of whether soldiers may or may not intentionally kill innocent noncombatants in pursuing their military objectives because it is substantial to reaffirm the moral requirement of balancing the lives of soldiers and the lives of noncombatants whom they are at risk of killing (Zohar 2014, 161-170). Since no belligerents are enemies by nature, Anthony Coates posits sustained recognition of 
the moral equality and the worth of the enemy as a logical outcome of "awareness of a moral community that transcends divisions and (...) secures the just limits of enmity" $(2006,218)$. In the quest for reaching the balance between the lives of soldiers and the lives of non-combatants, commanders and soldiers may act in a utilitarian fashion by turning to a non-lethal weapon on the grounds that it is more legitimate as being less evil tool comparing to the fatal effects of classical weaponry. From the perspective of this utilitarian reasoning, the practice of non-lethality despite all possible negative side-effects on the human body - could make less misery for outlawed fighters and civilians in the global periphery, while at the same time "rescue" them from illiberal chaos.

Nevertheless, the non-lethality as the military practice aimed at merely incapacitating human bodies could encourage slack or negligent resort to force among soldiers. In this regard, the practice of non-lethality may pose many threats to human security while lacking compatibility with the test for proportionality. For instance, if the dose or level of force a non-lethal weapon delivers cannot be varied or is found to be unreliable, then it cannot deliver a discriminate or proportional level of force. Pursued from the angle of their operational characteristics of precision, radius, repeatability, and selectivity, directed sound weapons or laser blinding weapons could be easily, but not necessarily intentionally, misused due to soldier's blind-spot-created incorrect assumption built on their designed non-lethality. The soldier may inflict irreversible injuries on others during combat operation simply by projecting a higher level of directed sound or laser beams, or in a longer period than it is originally instructed by the designer. In that case, the incorrect use of non-lethal weapons may originate from mistakes in judgment made in a haste, triggered by the stressful environment and chaotic conditions of combat. A soldier was not able to assess the adequate level of non-lethal force to project on enemies.

Far more serious controversies may arise around the various forms of likely malpractice of non-lethality. As an illustration, non-lethal weapons can be used in ways and for purposes that either were not originally intended by military planners or even contrary to issued orders. In this case, soldiers can intentionally use directed sound weapons or laser blinding weapons in the manner to "extract" extended effects on enemy fighters and civilians. Imprudent decision making may be rationalised on the morally wrong grounds that infliction of any sort of injury by a non-lethal force must, by disposition, be less wrongful action than the practice of killing. Embracing non-lethality as the silver bullet for effective policing of the global periphery may lead to a dramatic increase in soldiers become quicker on the trigger. The promise of benign characteristics of the non-lethality might dislocate soldiers from the reality of the battlefield full of manpower into a self-centred world of PC games, where a player (soldier) relates to fictional enemy fighters essentially as in Buber's $I-I t$ relationship. When using directed sound weapons or laser-blinding 
weapons on the battlefield against low-tech fighters of the global periphery, the soldier might feel himself as a fictional character from a sci-fi film, armed with a gun-mounted laser, neutralising a number of attacking opponents by simply clicking the buttons on a game console (or on a PC mouse). A portrayal of the morally disengaged and unemphatic logic of video games as an anticipated behavioural pattern of warfare in the 21st century underlines a likely profound downgrade in ethical decision making. In the depicted hypothetical cases, paying little heed to consequences reveals the hypothetical lack of moral sensitivity on the side of agents of non-lethal practice.

\section{BLOODLESS/RISKLESS WARFARE BUT FOR WHOM?}

The late modern warfare is being profoundly marked with military asymmetry, meaning that the military capability of one of the belligerents far exceeds that of the other, and this asymmetry is due in large part to the more powerful belligerent having weapons based on advanced technologies the other lacks. The huge technological gap between the United States and outlaw/failed states of the global periphery served as the starting point for Paul W. Kahn to conceptualise his paradigm of riskless warfare in an attempt to explain how combat situations in which the relationship of the mutual imposition of risk and mutual exposure to risk is constituted between belligerents meet standards of ethical conduct in war, but "the issue becomes more problematic when an army can destroy its enemies without any risk to its members' lives" $(2002,3)$. Kahn further argues that the permission to kill is "subject to a condition of reciprocity: Soldiers cannot defend themselves by threatening to injure unjust non-combatants" (2002, 3). Tracing Kahn's argument, Steven P. Lee (2012) contributes with the claim that the idea of reciprocal self-defence at the heart of combatant liability loses its hold in the reality of riskless warfare. Lee holds that "if combatants of the weak belligerent pose no risk to combatants of the strong belligerent, then the former to that extent lack threat liability, and attacks on them may not be justified" (2012, 225). While traditional warfare with soldiers facing reciprocal risks to their lives can be compared to a duel, riskless warfare can be summarised in the practice of manhunting.

In a speech delivered in the aftermath of the 9/11 attacks, George W. Bush explained that the United States, as "the leader of the free world", was required to "hunt down" terrorists and "bring [them] to justice" (White House 2003). The deliberate choice of those words discursively reflects one of the central ideas behind the US/West interventionism in the early 21 st century: treating the enemy as an ordinary outlaw/criminal who defies the law and should be imprisoned as soon as possible. This imperial politics of the manhunt ignores the absence of a formally declared state of war and thus inevitably erases the difference between the frontline and the rear, and consequently the distinction between the status of fighters and 
civilians. The asymmetry embedded in the disciplining wars that are being waged against the rebellious global periphery introduces the practice of the manhunt as a feasible military operational scenario. In this scenario, strategic outfoxing turns into a game of hide-and-seek with the fugitive, always trying to avoid capture, and the hunter trying to catch him alive.

Non-lethal weapons are an ideal means of disciplining the global periphery as they provide the option of selective control and management of outlawed social groups or entire local communities that (allegedly) produce insecurity for post-industrial societies of the global centre and privileged ones of the global periphery societies. This easily constitutes and sustains the border between "cooperative" and "rogue" geographical areas and political communities, so that the latter is excluded from the realm of universal protection of human rights and freedoms on the basis of claiming to be a threat to the (neo)liberal global order. According to Aihwa Ong (2006), neoliberal logic reconfigures territoriality by diversifying the space of the government and consequently degrading citizenship in terms of rights and benefits, as it creates separate zones of sovereignty in which different scopes of guaranteed human rights and freedoms are practiced. In this way, the population of rogue states or outlaw entities becomes the target of nonlethal weapons as the optimal means of controlling and suppressing civil unrest and thus is objected to invasive actions that directly undermine human rights by endangering the physical and psychological integrity of the individual. The logic of security risk management easily creates a legitimising basis for the acceptable, supposedly benign, and short-lived actions that non-lethal weapons provide against those who threaten the stability of the liberal order.

David A. Koplow $(2015,236)$ emphasises that, as a less hostile alternative to traditional firepower, non-lethality "may encourage the military to act precipitously, when the wiser course of action might actually be self-restraint". The risk that foreign policymakers would develop the practice of easily resorting to military interventions before the exhaustion of diplomatic means thanks to properties of non-lethal weapons that can provide small civilian casualties and material damage that would not resonate badly in the media. As with non-lethality, reduced war costs could encourage unnecessary and inappropriate resort to disciplining wars by the US and its Western allies, and later, by other global-power wannabes. Non-lethality would spur US and Western politicians to make more common use of armed conflict as a means of resolving international disputes and achieving foreign policy objectives since they could more easily justify military interventions to the public becoming more and more supportive of the "no body bags" policy. Some critical theorists focus on the dynamics of the complex of governmental practices related to the practice of non-lethality and its extra-local sites of governance in a rapidly expanding sphere of $21^{\text {st }}$-century interventionism. For instance, Seantel Anais lucidly observes that the use of non-lethal weapons - instead of alleviating anxiety 
stemmed from difficulties in managing unmanageable groups in the global periphery - in itself constitutes "threatening" parts of the population by shaping their collective identity by discursively fixing sources of insecurity to it (2011, 548-549). Anaïs holds that it is not clear anymore whether an insecure subject becomes a target or is just a result of the use of non-lethal weapons, which as a military tool should be a response to the challenges faced by policing hybrid political-criminalwarring entities that do not clearly fit into the categories of oppressed or threatening, i.e., those that transgress the line between two categories.

Bloodless or riskless warfare refers to the possibility of achieving military objectives by delivering undetectable harm to humans, that is through benign intervention on the body. As the notion of benignity is being coupled with the class of advanced weaponry, the late modern warfare opens a room for a substantive question: Would warfare remains ontologically the same if we succeed to permanently remove death and suffering from it with the help of non-lethal weapons? Warfare assumes the infliction of suffering and damage to impose the will of one's own political community on the will of another community, and it always presupposes a reciprocal relationship between the two conflicting parties. I suggest that the practices of non-lethality and the manhunt might collude to turn disciplining wars into a brand-new subgenre of reality television police shows. Global manhunt television shows would feed morally anaesthetised spectators of the global centre with real-time video imagery of combat operations in the planetary periphery. The monitoring of future military interventions in exotic scenery of "wild" Third World landscapes - in a safe and cosy home thousands of kilometres away from the battlefield - might eventually transform warfare into a new sport thanks to a thorough sanitising of combat operations through the benign practice of non-lethality. That would be a sort of the 21 st century Benthamian Panopticon designed to send a powerful message to the public in the West and worldwide in the form of factual, fictional, and factional representations of how the global centre controls and shapes the global periphery. As a prospective example of the I-It relationship, the new Benthamian Panopticon would erode the recognition of the enemy as a moral equal and a bearer of rights and legitimate interests, that is, the moral restraints of war would be loosened.

\section{CONCLUSION}

From time immemorial, the ontology of warfare has been intertwined with the major impacts of the ever-changing technological landscape on people caught up in armed conflicts - both soldiers and civilians. The development of weapons based on new technologies of the Fourth Industrial Revolution may have widespread collateral consequences in the matter of deaths, harm, and disruption preventing the civilian population from living peaceful lives. That was the main reason why I 
decided to investigate how the practice of non-lethality, built on recent advances in armament technology, may affect the ontology of warfare in the 21st century, particularly its substantive component - the ethical aspect of interpersonal dynamics. The main thesis that I have been endorsing is the idea that an anticipated development of non-lethal weapons may raise several controversies related to the assumed moral insensitivity of interventionist troops within the framework of US/West policing in the treatment of enemy fighters/combatants and the civilian population of the global periphery. In addition, I examined how the practice of non-lethality might turn enemy fighters and the civilian population into deviant outlaws devoid of moral value, which is "naturally" attributed to "civilised" nations gathered under the (neo)liberal global order.

I tested my hypothesis by scrutinising manufactured, conceived and non-lethal weapons currently under development and primarily based on technologies of directed energy and sound, with a focus on their operationally relevant structural characteristics of precision, radius, repeatability, and selectivity. The analysis of operational characteristics locates several nodes in which allegedly benign practice of non-lethality intersects with ethically unsound behavioural patterns. Universal moral worldview and social conventions on the appropriateness and inappropriateness of certain means of violence in armed conflicts praise the reversibility of non-lethality because this new military practice is likely to provide a "sanitised" manner in which violence could be enacted in the US/West-led interventionism legitimised on the liberal peace tenets. Military and academic discourse on bloodless/riskless warfare deceives political decision-makers and the public that there is a possibility of achieving military objectives by not harming human beings in a substantial way.

The proponents of the Western vision of war as a foreign policy instrument - utterly "purged" of the risk of moral wrongdoings - seem to turn a blind eye on the plausible negative effects of non-lethal weapons in combat situations. Albeit vehemently and persistently being marketed as benign for the human body, even delving into assumed negative effects of pursuing the non-lethal military practices - either caused by an unintentional incorrect use of non-lethal weapons or intentional misuse of technical features of these weapons - clearly demonstrates that the principles of distinction and proportionality could easily be weakened and obstructed in future combat operations in a not-so-obvious manner. The huge and ever-widening gap in military technology between the US/Western interventionist troops and warring entities and outlawed populations of the global periphery tends to disrupt the reciprocal relationship between the belligerents. Armed conflict between the high-tech and the low-tech parties is likely to turn into a police manhunt action pursued by the (neo)liberal intervening forces against the illiberal local outlaws. 
New sophisticated weaponry would in the long run devalue populations of the global periphery through their objectification by indifference and collateral victimisation as parts of routinised non-lethal procedures. Being benign at first glance, the practice of non-lethality coupled with the manhunt breaks the reciprocal dynamics between adversaries as a constitutive element of traditional warfare. Facing high-tech weaponry whose effects are beyond the comprehension of low-tech soldiers could be a traumatic event for them. Although the hidden psychological effects of encountering weapons based on technologies of directed energy and sound are yet to be carefully and systematically examined, the practice of nonlethality could without any doubt instil irrational fear and strong anxiety in persons who have experienced lasers or sound guns. The ruptured reciprocity would cut the ground for moral sensitivity and, consequently, for sound moral reasoning on the battlefield. Moral awareness also would become redundant in the fighting environment where combat actions are intentionally aimed only at incapacitating enemy combatants. If nobody gets killed by my combat action or avoids the imposition of irreversible harm, why then I ought to judge that action on moral grounds? Tracing that argument, the non-lethality eventually could oust enemy soldiers and civilians from the realm of moral concerns integral to military ethics.

In closing, I would like to leave the reader with one tension that is not resolved, that is the following ethical quandary: whether it would be moral to have a weapon that would act as a sort of Colonel Fenton's imaginary magic dust that puts people to sleep? By drawing attention to the way in which non-lethality might be inscribed upon the body in deceivingly less violent manners, this ethical quandary remains to be dealt with in future debates on the hidden dehumanising effects of high-tech weaponry practices.

\section{REFERENCES}

[AI \& ORF] Amnesty International and Omega Research Foundation (2015). The human rights impact of less lethal weapons and other law enforcement equipment. Retrieved from https://www.amnesty.org/download/Documents/ ACT3013052015ENGLISH.PDF.

Alexander, J. B. (1999). Future War: Non-Lethal Weapons in Modern Warfare. New York: St. Martin's Griffin.

Alexander, J. B. (2001). An overview of the future of non-lethal weapons. Medicine, Conflict and Survival 17(3), pp. 180-193.

Anais, S. (2011). Ethical interventions: Non-lethal weapons and the governance of insecurity. Security Dialogue 42(6), pp. 537-552.

Arnauld, A. [1683](1990). On True and False Ideas. Lewiston: Edwin Mellon Press. 
Atherton, K. D. (2020). What 'Less Lethal' Weapons Actually Do. Scientific American. June 23. Retrieved from https://www.scientificamerican.com/article/what-lesslethal-weapons-actually-do/.

Buber, M. (1937). I and Thou. Edinburgh and London: Morrison and Gibb.

Caron, J-F. (2020). Contemporary Technologies and the Morality of Warfare: The War of the Machines. Oxon and New York: Routledge.

Clarkeburn, H. (2002). A test for ethical sensitivity in science. Journal of Moral Education 31(4), pp. 439-453.

Coates, A. (2006). Culture, the Enemy and the Moral Restraint of War. In R. Sorabji and D. Rodin (eds), The Ethics of War: Shared Problems in Different Traditions (pp. 208-221). Aldershot: Ashgate.

Coleman, Stephen (2014). Ethical Challenges of New Military Technologies. In H. Nasu and R. McLaughlin (eds), New Technologies and the Law of Armed Conflict (pp. 29-41). Heidelberg: Springer.

Coleman, S. (2015). Possible Ethical Problems with Military Use of Non-Lethal Weapons. Case Western Reserve Journal of International Law 47(1), pp. 185-199.

US Department of Defense (2018). DoD Executive Agent for Non-Lethal Weapons (NLW), and NLW Policy, DoD Directive 3000.03E. Retrieved from https://www.esd.whs.mil/Portals/54/Documents/DD/issuances/dodd/ 300003p.pdf?ver=2018-10-24-112944-467.

Eken, E. M. (2017). Sanitization of War. In P. Joseph (ed.), The SAGE Encyclopedia of War: Social Science Perspectives (pp. 1516-1517). Thousand Oaks: SAGE Publications.

Enemark, C. (2008). 'Non-lethal' weapons and the occupation of Iraq: Technology, ethics and law. Cambridge Review of International Affairs 21(2), pp. 199-215.

Fidler, D. P. (2001). 'Non-lethal' weapons and international law: Three perspectives on the future. Medicine, Conflict and Survival 17(3), pp. 194-206.

Gregory, D. (2008). 'The rush to the intimate': Counterinsurgency and the cultural turn. Radical Pbilosophy 150, pp. 8-23.

Gross, M. L. (2008). The second Lebanon war: the question of proportionality and the prospect of non-lethal warfare. Journal of Military Ethics 7(1), pp. 1-22.

Gross, M. L. (2017). The Deaths of Combatants: Superfluous Injury and Unnecessary Suffering in Contemporary Warfare. In J. D. Ohlin, L. May, and C. Finkelstein (eds), Weighing Lives in War (pp. 111-128). Oxford: Oxford University Press.

Grossman, D. (1996). On Killing: The Psychological Cost of Learning to Kill in War and Society. Boston: Little, Brown and Company. 
Heidegger, M. (1982). The Basic Problems of Phenomenology. Bloomington: Indiana University Press.

Jabri, V. (2007). War and the Transformation of Global Politics. Basingstoke and New York: Palgrave MacMillan.

Jones, E. (2006). The Psychology of Killing: The Combat Experience of British Soldiers during the First World War. Journal of Contemporary History 41(2), pp. 229-246.

Jones, T. M. (1991). Ethical Decision Making by Individuals in Organizations: An Issue-Contingent Model. The Academy of Management Review 16(2), pp. 366-395.

Josephson, M. S. (2002). Making Ethical Decisions. Los Angeles (CA): Josephson Institute of Ethics.

Kahn, P. W. (2002). The Paradox of Riskless Warfare. Philosophy \& Public Policy Quarterly 22(3), pp. 2-8.

Kaurin, P. (2010). With Fear and Trembling: An Ethical Framework for Non-Lethal Weapons. Journal of Military Ethics 9(1), pp. 100-114.

Koplow, D. A. (2015). Red-Teaming NLW: A Top Ten List of Criticisms about Non-Lethal Weapons. Case Western Reserve Journal of International Law 47(1), pp. 229-238.

Korać, S. T. (2018). Rat u 21. veku kao sredstvo imperijalne kontrole planetarne 'periferije'. Medunarodni problemi LXX (4), str. 412-431.

Lee, S. P. (2012). Ethics and war: An introduction. Cambridge: Cambridge University Press.

MacDonald-Evoy, J. (2018, November 26). What is it like when the police use an LRAD 'sound cannon' to disperse a crowd? Arizona Mirror. Retrieved from https://www.azmirror.com/blog/ what-is-it-like-when-the-police-use-an-lradsound-cannon-to-disperse-a-crowd/.

McLaughlin, E. (2007). The New Policing. London and Thousand Oaks: SAGE Publications.

NATO Parliamentary Assembly (2001). Special Report Emerging Technologies and Their Impact on Arms Control and Non-Proliferation. Retrieved from https://www.bits.de/NRANEU/BMD/documents/NATO-PA $\% 20 \mathrm{New} \% 20$ Technologies.pdf.

NATO (2006). The Human Effects of Non-Lethal Technologies, The Final Report of NATO RTO HFM-073. The Research and Technology Organisation of NATO. Retrieved from https://www.sto.nato.int/publications/STO $\% 20$ Technical\%20Reports/RTO-TR-HFM-073/\$\$TR-HFM-073-ALL.pdf. 
Nordin, A. H.M. and Öberg, D. (2015). Targeting the Ontology of War: From Clausewitz to Baudrillard. Millennium: Journal of International Studies 43(2), pp. 392-410.

Norman, R. (1995) Ethics, killing and war. Cambridge: Cambridge University Press.

Ong, A. (2006). Neoliberalism as Exception: Mutations in Citizenship and Sovereignty. Durham \& London: Duke University Press.

Porch, D. (2013). Counterinsurgency: Exposing the Myths of the New Way of War. Cambridge: Cambridge University Press.

Rest, J. R. (1994). Background: Theory and Research. In J. R. Rest and D. Narvaez (eds). Moral development in the professions: Psychology and applied ethics (pp. 1-25). Hillsdale (NJ): Erlbaum.

Scheipers, S. (2014). Counterinsurgency or irregular warfare? Historiography and the study of 'small wars'. Small Wars \& Insurgencies 25(5-6), pp. 879-899.

Searle, J. R. (1999). Intentionality: An essay in the philosophy of mind. Cambridge: Cambridge University Press.

Shah, N. (2017). Death in the details: Finding dead bodies at the Canadian War Museum. Organization 24(4), pp. 549-569.

Siniscalchi, J. (1998). Non-Lethal Technologies: Implications for Military Strategy, Occasional Paper No. 3. Center for Strategy and Technology, Air War College, Air University, Montgomery. Retrieved from https://fas.org/man/dod101/sys/land/docs/occppr03.htm.

Small Arms Survey (2020). Less-lethal Weapons. Retrieved from www.small armssurvey.org/weapons-and-markets/products/less-lethal-weapons.html.

Steverson, L. A. (2008). Policing in America: A reference bandbook. Santa Barbara, CA: ABC CLIO.

Swinburne, R. (2013). Mind, Brain, and Free Will. Oxford: Oxford University Press.

Van Creveld, M. (1991). The Transformation of War. New York: Free Press.

Watson, P. (1980). War on the mind: The military uses and abuses of psychology. Harmondsworth: Pelican books.

White House (2003, February 14). President Speaks at FBI on New Terrorist Threat Integration Center. Office of the Press Secretary. Retrieved from https:// fas.org/irp/news/2003/02/ wh021403b.html.

Young, R. (1979). What Is So Wrong with Killing People? Pbilosopby 54(210), pp. $515-528$.

Zehfuss, M. (2018). War and the Politics of Ethics. Oxford: Oxford University Press.

Zohar, N. (2014). Risking and Protecting Lives: Soldiers and Opposing Civilians. In H. Frowe and G. Lang (eds), How We Fight: Ethics in War (pp. 155-171). Oxford: Oxford University Press. 


\section{RATOVANJE U DOBA POZNE MODERNOSTI I KONTROVERZE NESMRTONOSNOSTI}

Apstrakt. Rad nastoji da istraži kako praksa nesmrtonosnosti, zasnovana na nedavnim tehnološkim dostignućima u razvoju naoružanja, može da deluje na ontologiju ratovanja u 21. veku pretvaranjem neprijateljskih vojnika i civilnog stanovništva u devijantne odmetnike bez moralne vrednosti „normalne” za civilizovane nacije okupljene pod okriljem (neo)liberalnog globalnog poretka. Autor analizira praksu nesmrtonosnosti u kontekstu vojnih operacija preduzetih u okvirima američkog/zapadnog policijskog delovanja usmerenog na očuvanje reda na globalnoj periferiji. Autor polazi od pretpostavke da predvidljiv razvoj nesmrtonosnog oružja već sada otvara više kontroverznih pitanja proisteklih iz odsustva moralne osećajnosti intervencionističkih trupa u postupanju prema neprijateljskim borcima i civilnom stanovništvu. Hipoteza se propituje sa teorijskih pozicija kritičkog pristupa izučavanju međunarodne bezbednosti i ontologije ratovanja, kao i iz perspektive filozofije uma i normativnog pristupa moralnog delatništva. Autor zaključuje da se čini da zapadna vizija rata kao spoljnopolitičkog sredstva potpuno pročišćenog od rizika moralno pogrešnog postupanja, namerno previđa moguće negativne učinke nesmrtonosnog oružja u borbenim situacijama. Suprotno očekivanjima i vojnim strateškim vizijama, postoji verovatnoća da će praksa nesmrtonosnosti u spoju sa praksom lova na glave izmestiti neprijateljske vojnike i civile van područja moralnih obzira kao nerazdvojivog dela vojne etike.

Ključne reči: nesmrtonosnost, nesmrtonosno oružje, ontologija ratovanja, vojna intervencija, vojna tehnologija, naoružanje, vojna etika, moralno delatništvo.

Received: 15/10/2020

Accepted: 05/11/2020 